Fig. 1 Atlantoaxial subluxation with a separation of $9 \mathrm{~mm}$.

The patient was initially treated by skull traction. with some reduction of the subluxation. Two weeks later he underwent atlantoaxial fusion with interlaminar wiring. Clinical improvement was gradual, but by three months there was sound fusion and a full neurological recovery except for minor ankle clonus.

The exact pathology of atlantoaxial subluxation in psoriatic arthropathy is uncertain, but it is likely that an inflammatory arthritis with soft tissue involvement and synovial proliferation in the synovial joints around the odontoid peg results in degeneration of the adjacent transverse ligament. It is not certain whether pannus plays any part in the compression, as occurs in rheumatoid arthritis.

In conclusion, this report confirms an association, albeit uncommon, of atlantoaxial subluxation with psoriatic arthropathy, and emphasises the potentially dangerous nature of this complication.

Westminster Hospital.

Dean Ryle Street,

C T PEASE

London SW1P 2AP

J L POZO

Royal National Orthopaedic Hospital, E J P CRAWFORD Brockley Hill,

Stanmore,

Middlesex HA7 4LP

\section{HLA-B27 in Turkish patients with rheumatoid arthritis}

SIR, Isomaki et al initially reported an increased prevalence of HLA-B27 in rheumatoid arthritis (RA) in Finland. ' Later, two studies from Turkey pointed out that this was also true for Turkish patients, but with a lower prevalence $\triangle$ of B27 both among the patients and the healthy population. ${ }^{23}$

In the study from our laboratory, of 50 consecutive, seropositive (by latex agglutination) patients with RA, the prevalence of HLA-B27 was $7 / 50(14 \%)$, whereas the prevalence of the same allele was $8 / 268(3 \%)$ among healthy controls $\left(\chi^{2}=9 \cdot() 6, p<0 \cdot 01\right) .^{3}$ The prevalence of the only other allele investigated in this study, HLA-B5, $\vec{\sigma}$ was $30 \%$ among the patients and $33 \%$ among controls.

Recently we had the opportunity to reassess our findings. Thirty two Turkish patients with definite or $\vec{\infty}$ classical $\mathrm{RA}^{+}$were HLA typed in Leiden, Holland as part 0 of a study with Dr J D Perry of London, to compare the severity of disease in English and Turkish patients.

The prevalence of HLA-B27 was $6 / 32$ (19\%) among $\mathbb{D}$ patients and $3 / 50(6 \%)$ among controls, confirming our $\frac{D}{D}$ earlier observation. This approached the conventional $\frac{1}{3}$ significance level if it is accepted that the corrected $p$ value is not used if a significant association has previously been shown $^{5}\left(\mathrm{RR}=3 \cdot 22, \chi^{2}=3 \cdot 06, \mathrm{p}=0 \cdot 076\right)$. The prevalence $\& \mathrm{f} \overrightarrow{\mathrm{O}}$ DR4 was $14 / 32(44 \%)$ among patients, whereas it wo $11 / 50(22 \%)$ among controls $\left(\mathrm{RR}=2 \cdot 69, \chi^{2}=4 \cdot 3\right.$ $\mathrm{p}=0 \cdot 035)$.

The Ural-Altaic hypothesis ${ }^{6}$ claims that there are linguistic ties between the Turks and the Finns. ${ }^{5}$ The association of RA with HLA-B27 may be another link 气 supporting this hypothesis.

Division of Rheumatology,

Department of Medicine,

Cerrahpaşa Medical Faculty,

University of Istanbul

and

Department of Immunohematology,

University Hospital.

Leiden,

The Netherlands

\section{References}

1 Isomäki H. Koota K. Martio J. Tiilikainen A. HLA-B27 and rheumatoid arthritis. Scand J Rheumatol /Suppl] 1975; 4: 30-9. D

2 Akokan G. Koral N. Spondilartrit ve romatoid artritte HLA antijenleri. Tip Fakültesi Mecmuasi 1977: 40: 502-7.

3 Yazici H. Özbakir F. Yurdakul S, Müftüoğlu A. The prevalence of HLA-B27 is increased in rheumatoid arthritis in Turkey $N$ [Abstract] Proceedings of The 5th European Immunology
Meeting. 1982: 213.

4 Ropes M W. Bennett G A, Cobb S, Jacox R. Jessar R A. 1958 O revision of diagnostic criteria for rheumatoid arthritis. Bult Rheum Dis 1958: 9: 175-6.

5 Svejgaard A. Jersild C, Staub Nielsen L, Bodmer W F. HL-A ̄ antigens and disease: statistical and genetical considerations.? Tissue Antigens 1974: 4: 95-105.

6 Altaic language. In: Encylopaedia Britannica 15 th ed. Chicago: William Benton. 1974: 635-9. 